\title{
CYANIC ACID, PHYTIC ACID, TOTAL TANNIN AND AFLATOXIN CONTENTS OF A BRAZILIAN (NATAL) MULTIMISTURA PREPARATION
}

\author{
CONTEÚDOS DE ÁCIDO CIANÍDRICO, ÁCIDO FÍTICO, TANINO TOTAL E \\ AFLATOXINA EM UMA PREPARAÇÃO BRASILEIRA (NATAL) DE MULTIMISTURA
}

\author{
Francisca Sônia CÂMARA' \\ Marta Suely MADRUGA²
}

\begin{abstract}
The utilization of a "multimistura" as food supplement, in nutritional improvement programs for the low-income population in Brazil, represents a low-cost and easy-to-use food preparation alternative, presentig reasonable nutritive value and satisfying local taste preferences. This is based on the fact that the "multimistura" is made up of non-conventional ingredients/foods and of agroindustrial by-products, rich in different nutrients. This paper was designed to determine some toxic and/or antinutritional factors of a "Multimistura" utilized as food supplement in institutional programs to prevent malnutrition by the Department of Welfare and Social Affairs of the City of Natal, RN. The product studied had the following formulation: $30 \%$ of wheat bran; $30 \%$ of wheat flour; $30 \%$ of corn meal; $3 \%$ of powder from cassava leaves; $4 \%$ of pumpkin seeds powder; and 3\% of eggshell powder. The analysis of the main toxic and/or antinutritional factors showed very low concentrations of phytates and tannins and no detectable levels of aflatoxin and cyanic acid.
\end{abstract}

Index terms: "multimistura", aflatoxins, cyanic acid, phytates, tannins.

RESUMO

O uso da "multimistura" como suplemento alimentar, em programas de intervenção nutricional para populações brasileiras carentes, vem se apresentando como uma alternativa alimentar de valor nutritivo razoável, baixo custo, preparo rápido e paladar regionalizado. Isto resulta do fato desta ser constituída principalmente de alimentos não convencionais e/ou subprodutos agro-industriais ricos em diferentes nutrientes. Este trabalho teve como objetivo dosar alguns fatores tóxicos e/ou antinutricionais de uma "multimistura" utilizada como suplemento alimentar em programas institucionais no combate à desnutrição da Secretaria Municipal de Promoção Social da cidade de Natal. O produto analisado tinha a seguinte formulação: 30\% de farelo de trigo; 30\% de farinha de trigo; 30\% de fubá de milho; $3 \%$ de pó de folha de mandioca; $4 \%$ de pó de semente de jerimum; $3 \%$ de pó de casca de ovo. As análises dos principais fatores tóxicos e/ou antinutricionais mostraram baixíssimas concentrações de fitatos e taninos e níveis não detectáveis de aflatoxinas e ácido cianídrico.

Termos de indexação: multimistura, aflatoxinas, ácido cianídrico, fitatos, taninos.

\footnotetext{
(1) Departamento de Tecnologia Farmacêutica e de Alimentos, Universidade Federal do Rio Grande do Norte.

(2) Departamento de Tecnologia Química e de Alimentos, Centro de Tecnologia, Universidade Federal da Paraíba. Campus I, Cidade Universitária, 58059-900, João Pessoa, Paraíba, PB, Brasil. Correspondência para/Correspondence to: M.S. MADRUGA.
} 


\section{INTRODUCTION}

According to data from UNICEF (1994), malnutrition in children under 5 years is a problem in Brazil. Efforts and many alternative interventions have been implemented to combat the problem (Oliveira et al., 1977; Organización Panamericana..., 1989). Since 1986, the use of alternative foods has been incorporated into the routine work of governmental and non-governmental institutions, such as the National Health Foundation (Fundação Nacional de Saúde) and the Children Affairs (Pastoral da Criança-CNBB), to reduce national malnutrition (Organización Panamericana..., 1989; Beausset, 1992; Unicef, 1994; Bion et al., 1997).

The "multimistura" was developed in 1988 by Brandão as a food supplement for pregnant women and children to combat malnutrition (Brandão \& Brandão, 1988; Brandão, 1996). It has been formulated from by-products such as: wheat and rice bran; powder from cassava, sweet potatoes and purslane leaves; powder from pumpkin, watermelon and melon seeds; eggshell powder, etc. (Brandão \& Brandão, 1988; Câmara \& Madruga, 1996; Santana et al., 1996; Bion et al., 1997). Although the use of such by-products has been recommended as good sources of macro/ micronutrients (Beausset, 1992; Brandão, 1996; Madruga \& Câmara, 1997; Madruga \& Câmara, 1999), and they have very low cost, their utilization as a nutritional alternative has been controversial, since some ingredients are also recognized as good sources of toxic and antinutritional substances, such as: cyanic acid, phytates, tannins, etc. (Torin, 1991; Câmara, 1996; Santana et al., 1996; Câmara \& Madruga, 1997).

This study was carried out to obtain information related to the presence of some toxic and/or antinutritional factors in an alternative food supplement, "multimistura", utilized in institutional food supplementation programs to combat and prevent malnutrition, in the city of Natal, Rio Grande do Norte, Brazil.

\section{MATERIAL AND METHODS}

\section{Sample}

The sample analyzed was a food supplement, named "multimistura", which is used in the governmental programs, in the Northeast of Brazil (Natal, RN), to prevent and combat malnutrition in children from 6 months to 5 years of age. Three samples were collected in distinct periods in 1995 (January, May and September) from local production "ATIVA" (Social Activity Association). Approximately $1 \mathrm{~kg}$ of each sample was obtained from ten sub-samples (around $100 \mathrm{~g}$ ), which were acquired from different parts of the whole production. After collection, sub-samples were mixed, packed in $1 \mathrm{~kg}$ polypropylene bags and transported to the laboratory.

The "multimistura" was formulated with the following ingredients: $30 \%$ of wheat bran, $30 \%$ of wheat flour, $30 \%$ of corn meal, $3 \%$ of cassava leaf powder, $4 \%$ of pumpkin seed powder and $3 \%$ of eggshell powder. It was prepared according to the ATIVA process (Câmara, 1996; Madruga \& Câmara, 1999). Since the ingredients were in the form of powder, the preparation process consisted basically of weighing and mixing the ingredients. However, before formulation the ingredients were submitted to drying, roasting, blending, grinding and sieving.

- Cassava leaves: They were selected, washed and dried in the shade at ambient temperature $\left(32^{\circ} \mathrm{C}\right)$ for five days. Next, the dried leaves were ground three consecutive times in a mill, using a $0.8 \mathrm{~mm}$ mesh screen. The powder obtained was then sieved and packed in plastic bags.

- Pumpkin seeds: initially the seeds were washed in tap water to remove impurities, sand, and pieces of fruit. Then they were dried in the sun at $38^{\circ} \mathrm{C}$ for 72 hours. After cleaning and drying the seeds were selected and roasted in an aluminum pan by mixing with a wooden spoon on a domestic stove. The roasted seeds were ground, sieved and packed in plastic bags.

- Eggshells: by submerging the broken shells in a bowl containing tap water, residues were eliminated. Subsequently, the shells were submerged in a $1 \%$ chlorine solution for $10 \mathrm{~min}$, for disinfection. After disinfection, they were washed in tap water, and the internal skin was removed. The shells were dried in the sun for 24 hours, ground and sieved in a cheesecloth to obtain a fine powder, which was packed in plastic bags.

- Wheat bran: broken grains were eliminated from the wheat bran through sieving, using a straw sieve. The bran was roasted for 20min in a large aluminum pan, mixing continuously. Then, it was cooled and packed in plastic bags.

- Wheat flour and corn meal: they were roasted separately in large aluminum pans for $20 \mathrm{~min}$. Then, they were cooled and packed in plastic bags.

\section{Analyses}

The cyanic acid contents were determined in the "multimistura" and in the cassava leaves powder and raw cassava leaves, according to the argentometric method (Association of Official..., 1984) procedure 9113 - based upon final titration of cyanide by iodo-silver.

The presence of phytic acid was determined in the "multimistura" and in the wheat bran, following the method described by Harland \& Oberleas (1997).

The Association of Official Analytical Chemist method procedure 9110 - was used for determining tannins in the "multimistura" and in the cassava leaves powder (Association of Official..., 1984). This method measures the reduction of molybdotungstate reagent (Folin-Denis) by the tannin substances spectrophotometrically at 760nm. 
Table 1. Toxic and/or anti-nutritional factors of "multimistura" and some of its constituents.

\begin{tabular}{|c|c|c|c|c|}
\hline Samples & Multimistura $^{1}$ & Cassava leaves powder ${ }^{1}$ & Raw cassava leaves $^{1}$ & Wheat meal $^{1}$ \\
\hline Cyanic acid (mg/kg) & not detected & $72.0 \pm 8.9$ & $309.0 \pm 10.5$ & not analyzed \\
\hline Phytic acid (mg/100g) & $1.04 \pm 0.14$ & not: analyzed & not analyzed & $1.28 \pm 0.03$ \\
\hline Tannins (mg/100g) & $277.62 \pm 20.45$ & $996.25 \pm 31.09$ & not analyzed & not analyzed \\
\hline Aflatoxin ( $\mu \mathrm{g} / \mathrm{kg})$ & not detected & not analyzed & not analyzed & not analyzed \\
\hline
\end{tabular}

(1) $\bar{X} \pm$ SD. Number of samples is three with three replicate for each toxic and/or anti-nutritional factors.

The presence of aflatoxin was determined only in the "multimistura", according to the method of Soares \& Rodriguez-Amaya (1989). This method followed an analysis in thin-layer chromatography, with preliminary extraction and clean-up.

\section{RESULTS AND DISCUSSION}

The presence of cyanic acid was determined to check the efficiency of the drying process of the cassava leaf. According to the data in Table 1, the five-day drying process was very efficient, since it resulted in a reduction of $75 \%$ in the cyanic acid content in the cassava leaves powder $(72 \mathrm{mg} / \mathrm{kg})$, when comparing with the initial concentrations in the raw leaves $(309 \mathrm{mg} / \mathrm{kg}$ ). These data are in accordance with those presented by Vitti et al. (1972), who reported reduction of $70 \%$ in cyanic acid in the raw leaves of cassava during the dehydration process.

The fact that cyanic acid was not detected in the "multimistura" probably resulted from the low concentration of cassava leaf powder (3\%) in the formulation of the product, the amount being below the limit of detection of the method which is $0.3 \mathrm{mg} / \mathrm{kg}$. According to Beausset (1992), the likely absence of cyanide ion in the "multimistura" does not affect the quality of the product, considering the proportion in which it is formulated.

The phytic acid analysis in the "multimistura" and wheat bran samples showed concentrations of 1.04 and $1.28 \mathrm{mg} / 100 \mathrm{~g}$, respectively, which did not represent a great difference between the two samples. The amount of phytic acid in these products was below those reported by Torin (1991) and Weber \& Chaudhary (1987), which were 4.9 to $6.9 \%$ of phytic acid in rice bran.

High concentrations of phytic acid usually found in bran products are extremely important, considering that phytic acid can act as a chelating agent of metal ions, reducing the absorption of minerals, such as zinc, calcium, magnesium and iron, during the digestion process (Erdman, 1979; Champagne, 1985; Câmara \& Madruga, 1997; Oliveira et al., 1997).

The non-appearance of aflatoxin $B_{1}, B_{2}, G_{1}, G_{2}$ in the "multimistura" analyzed here was an indication of the good quality of these ingredients and of the processing and storage conditions. In fact, it also indicated that the samples were in accordance with the legislation (number 56/94, MERCOSUL/GM), (Brasil, 1996), which establishes limits of $20 \mathrm{mg}$ of aflatoxin $B_{1}$ and $\mathrm{G}_{1}$ per $\mathrm{kg}$ of products. The content of tannins found in the "Multimistura" (277.62 mg/kg) was even below the minimum limit reported in the literature, as toxic for laboratory animals (Costa, 1977).

\section{CONCLUSION}

The samples of "multimistura" obtained from ATIVA (Natal, RN) for this study showed non-detectable levels of aflatoxin or cyanic acid. Meanwhile, low concentrations of phytates and tannins were found.

\section{REFERENCES}

ASSOCIATION OF OFFICIAL ANALYTICAL CHEMISTS. Official Methods of Analysis of AOAC. 14.ed. Washington DC : The Association, 1984. 1141p.

BEAUSSET, I. Estudio de las bases cientifícas para el uso de alimentos alternativos en la nutrición humana. Brasília : INAN, 1992. 52p.

BION, F.M., PESSOA, D.C.N.P., LAPA, M.A.G. Uso de uma multimistura como suplementação alimentar: estudos em ratos. Archivos Latinoamericanos de Nutrición, Guatemala, v.47, n.3, p.242-247, 1997.

BRANDAO, T.T.C., BRANDAO, R.F. Alimentação alternativa. Bulletin I. Betim : [s.n], 1988. 130p.

BRANDAO, T.T.C. Alimentação alternativa. Bulletin II. Brasília : INAN, 1996. p.95.

BRASIL. Mercosul/GMC. Resolução n56/94. Portaria no 183, de 21 de março de 1996. Estabelece regulamento técnico sobre limites máximos de aflatoxinas. Diário Oficial [da República Federativa do Brasil], Brasília, 25 de março de 1996.

CÂMARA, F.S. Multimistura: composição química, fatores tóxicos e/ou antinutricionais. João Pessoa, 1996. 64p. Dissertação (Mestrado em Ciência e Tecnologia de Alimentos) - Centro de Tecnologia, Universidade Federal da Paraíba, 1996.

CÂMARA, F.S., MADRUGA, M.S. Avaliação química e nutricional de uma multimistura utilizada como suplemento alimentar na 
alimentação humana. In: CONGRESSO BRASILEIRO DE CIÊNCIA E TECNOLOGIA DE ALIMENTOS, 15., 1996, Poços de Caldas. Resumos... Poços de Caldas : Sociedade Brasileira de Ciência e Tecnologia de Alimentos, 1996. p.91.

CÂMARA, F.S., MADRUGA, M.S. Avaliação dos fatores tóxicos e/ou antinutricionais de uma multimistura utilizada como suplemento alimentar em comunidades carentes em Natal, RN. In: ENCONTRO NACIONAL DE ANALISTAS DE ALIMENTOS, 10., 1997, Manaus. Resumos... Manaus : Sociedade Brasileira de Analistas de Alimentos, 1997. p.17.

CHAMPAGNE, E.T. The interactions of minerals, proteins and phytic acid in rice bran. Cereal Chemistry, St. Paul, v.62, n.4, p.231-238, 1985.

COSTA, C.P. Efeito dos taninos do pseudo-fruto de caju sobre o desenvolvimento de ratos. In: ENCONTRO DE ANALISTA DE ALIMENTOS, 1977, Goiás. Anais ... Goiás : Sociedade Brasileira de Analistas de Alimentos, 1977. p.12.

ERDMAN, J.W. Oilseed phytates: nutritional implications. Journal of American Oil Chemistry of Society, v.56, n.8, p.736-741, 1979.

HARLAND, B.F., OBERLEAS, D. Determination of phytic acid in flour. Cereal Chemistry, St. Paul, v.54, p.827-832, 1977.

MADRUGA, M.S., CÂMARA, F.S. Multimistura: teor de proteínas e aminoácidos. In: SIMPÓSIO LATINO AMERICANO DE CIÊNCIA DE ALIMENTOS, 2., 1997, Campinas. Resumos... Campinas : Faculdade de Engenharia de Alimentos, 1997. p.177. (UNICAMP).

MADRUGA, M.S., CÂMARA, F.S. Chemical composition of "multimistura" a food supplement. Food Chemistry Barking. 68, p. 41-44, 2000.

OLIVEIRA, E.M., FERNANDES, N.R.A., BOAVENTURA, G.T. Qualidade protéica da dieta consumida por crianças desnutridas do município de Quissamã e adicionada de alimentos não convencionais: estudo em ratos. Niterói, 1997. Monografia
(Curso de Graduação em Nutrição) - Universidade Federal Fluminense, 1997.

ORGANIZACIÓN PANAMERICANA DE LA SALUD. Por una mejor alimentación. Washington DC, 1989.30p. (Cuaderno Técnico, n.25).

SANTANA, L.F.R., COSTA, N.M., FERREIRA, G. Valor nutritivo de "multimisturas" utilizadas como alternativas alimentar. In: CONGRESSO NACIONAL DA SOCIEDADE BRASILEIRA DE ALIMENTAÇÃO E NUTRIÇÃO, 4., 1996, São Paulo. Anais... São Paulo : Sociedade Brasileira de Alimentação e Nutrição, 1996. p.9.

SOARES, L.M., RODRIGUEZ-AMAYA, D.B. Survey of Aflatoxin, Ochratoxin A, Zearalenone and Sterigmatocystin in some Brazilian foods by using Multi-toxin Thin-layer Chromatography Method. Journal of Association of Official Analytical Chemists, Washingyon DC, v.72, n.2, p.22-26, 1989.

TORIN, H.R. Utilização do farelo de arroz industrial: composição e valor nutrificante em dietas recuperativas. Campinas, 1991. 147p. Dissertação (Mestrado em Ciência e Tecnologia de Alimentos) - Faculdade de Engenharia de Alimentos, Universidade Estadual de Campinas, 1991.

UNICEF. Alimentação alternativa: aspectos nutricionais e sociais. Fortaleza : [s.n], 1994.17p. (Informe Técnico).

VITTI, P., FIGUEIREDO, I.B., ANGELUCCI, E. Folhas de mandioca desidratada para fins de alimentação humana. Coletânea do Ital, Campinas, v.4, p.117-125, 1971-1972.

WEBER, F.E., CHAUDHARY, V.K. Recovery and nutritional evaluation of dietary fibber ingredients from a barley by-products. Cereal Foods World, St. Paul, v.32, n.8, p.548-550, 1987.

Recebido para publicação em 24 de outubro de 1999 e aceito em 9 de março de 2000. 